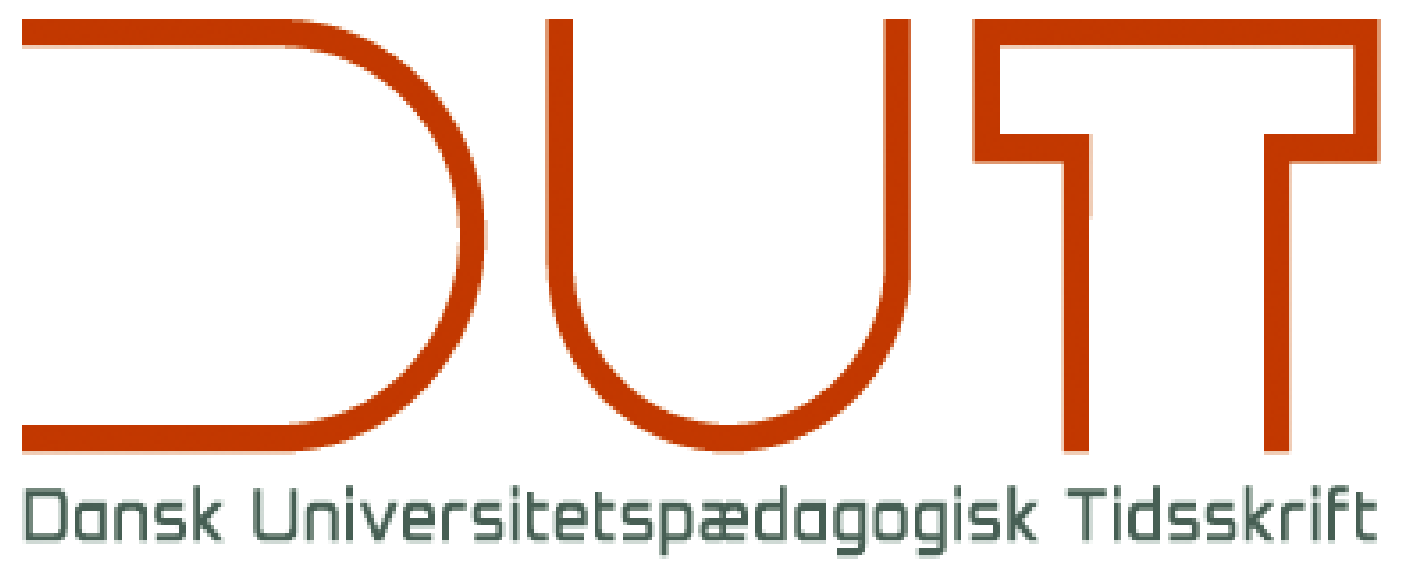

Tema

Forfattere

Sidetal

Udgivet af

URL

Fra data til beslutninger

Årgang 14 nr. 26 / 2019

DUT Guide om akademisk skrivning

Tine Wirenfeldt Jensen

$115-124$

Dansk Universitetspædagogisk Netværk, DUN

> http://dun-net.dk/

Betingelser for brug af denne artikel

(C) Copyright
Denne artikel er omfattet af ophavsretsloven, og der må citeres fra den. Følgende betingelser skal dog være opfyldt:

- Citatet skal være i overensstemmelse med "god skik"

- Der må kun citeres „i det omfang, som betinges af formålet“

- Ophavsmanden til teksten skal krediteres, og kilden skal angives ift. ovenstående bibliografiske oplysninger.

DUT og artiklens forfatter 


\title{
DUT Guide om akademisk skrivning
}

\author{
Tine Wirenfeldt Jensen ${ }^{\mathrm{a}, 1}$ \\ ${ }^{\mathrm{a} M E T o D o}$ og SDU Universitetspædagogik, Syddansk Universitet
}

\begin{abstract}
At kunne skrive er ikke bare en forudsætning for at kunne bestå eksamener på videregående uddannelser, det er også en metode til at lære sit fag og kunne gå i dialog med det. Alligevel er systematiske indsatser på området relativt sjældne på danske videregående uddannelser. Det betyder, at den enkelte underviser kan opleve at stå alene med opgaven med at støtte de studerende i at opbygge de nødvendige skrivekompetencer.

På baggrund af forskningslitteratur præsenterer artiklen ni tips til at understøtte udviklingen af akademiske skrivekompetencer og læring henvendt til undervisere. Rammen er et undervisningsforløb, og tipsene kan også bruges i vejledningen.
\end{abstract}

\section{Baggrund}

Lea og Street (1998) tilbyder en nuanceret forståelsesramme for studerendes skrivning på videregående uddannelser, og rammen tjener samtidig til at indfange udviklingen på feltet på et overordnet niveau. Lea og Street (1998) identificerer tre modeller for akademisk skrivning: som studieteknik, som akademisk socialisering eller som akademisk literacy.

I en studieteknisk optik forstås skrivning som en teknisk færdighed, der uproblematisk kan overføres på tværs af kontekster, og som studerende burde mestre ved studiestart. I modellen akademisk socialisering opfattes studerendes skrivning som en del af en større socialiseringsproces ind i den akademiske kultur. I et akademisk literacy-perspektiv forstås akademisk kultur hverken som en homogen eller statisk størrelse. Skrivning opfattes som en social praksis med fokus på at skabe og udfordre mening, en praksis som er tæt forbundet med fagenes vidensforståelser og de studerendes identitetsudvikling.

Selvom forfatterne giver modellen akademisk literacy forrang, så afviser de ikke de to andre forståelser, men opfatter dem som indlejrede i hinanden, således at akademisk literacy medtænker de to første modeller i en større kontekst. De tre modeller vægter i stigende grad fagdisciplinens betydning for skriveudvikling og læring. Akademisk literacy-forståelsen synliggør, at akademisk skrivning ikke meningsfuldt kan adskilles fra faglig læring (Dysthe et al., 2001). Samtidig åbner forståelsen et refleksionsrum for at diskutere fagets vidensformer og videnskabsteoretiske positioner.

Lea og Streets modeller kan bruges som refleksionsramme for underviseres tiltag i forhold til studerendes skrive- og læreprocesser. Den omfangsrige håndbogslitteratur på området (Booth et al., 2016; Rienecker og Jørgensen, 2017, m.fl.) kan fx kritiseres for at være udtryk for studieteknikmodellen (Hagström, 2005), men med Lea og Streets forståelse af de tre modeller som indeholdt $\mathrm{i}$ hinanden er det muligt som underviser at forankre udvalgte dele af denne type materiale i faget. Det forudsætter et fokus på at koble materialet til faget og dets

\footnotetext{
${ }^{1}$ Kontakt: tine@metodo.dk
} 
vidensformer og give plads til fælles diskussion og kritik. På samme måde kan peer feedback forstås som en del af en akademisk socialiseringsproces, men ved at give plads til kritisk dialog om fagets videnskabsteoretiske positioner, traditioner og konventioner kan aktiviteten også forstås i et akademisk literacy-perspektiv.

De forskellige fag stiller i kraft af deres vidensforståelser også forskellige medierende redskaber til rådighed for de studerendes skrivning (Blåsjö, 2004), og i arbejdet med at understøtte akademisk skrivning er det afgørende, at der eksisterer en tæt kobling til den konkrete fagdisciplin (Carter et al., 2007). Faglige undervisningsforløb indeholder dermed et stort potentiale til at understøtte studerende i at oparbejde akademiske skrivekompetencer. Særlig hvis undervisningen ikke reduceres til kun at have et normativt sigte, men at skrivning også opfattes som en vigtig arena for, at studerende kan lære deres fag og udvikle en selvstændig faglig identitet og stemme (Ivanič, 1998).

\section{Praksispunkter}

- Sørg for overensstemmelse mellem skriftlige eksamener, opgavens

læringsmål og undervisningen

- Brug skrivning til at understøtte læreprocessen

- Ekspliciter vurderingskriterier

- Synliggør argumentationens rolle

- Diskuter forventningerne til selvstændighed i opgaven

- Diskuter krav til akademisk sprog

- Understøt problemformulerings- og litteratursøgningsprocessen

- Giv redskaber til at kvalificere skriveprocessen

- Integrer struktureret peer feedback og selvevaluering

\section{Tip 1}

\section{Sørg for overensstemmelse mellem skriftlige eksamener, opgavens læringsmål og undervisningen}

At der bør være en intern sammenhæng (alignment, Biggs \& Tang, 2007) i uddannelsesaktiviteter er ikke nyt. Alligevel er det ikke altid, at der er den nødvendige overensstemmelse mellem en skriftlig opgave som eksamensform, de opstillede læringsmål for opgaven og så tilrettelæggelsen af den undervisning, de studerende deltager i undervejs i forløbet. Hvis eksamensformen er skriftlig, bør underviseren sikre, at forløbet indeholder rige muligheder for, at de studerende skriver og får feedback på deres tekster. Dette gælder uanset eksamensformen (bundet eller selvstændig problemformulering, hjemme eller stedbundet, få timer eller måneder til rådighed). Brugen af en arbejdsportfolio i undervisningen kan være en metode til 
at give de studerende mulighed for løbende at producere, samle og reflektere over tekst produceret i undervisningen, og portfolio kan også på forskellige måder danne udgangspunkt for den endelige bedømmelse (Dysthe \& Engelsen, 2003).

Som underviser har man et begrænset råderum i forhold til de rammer, der er fastlagt for undervisningens mål og prøveformer. Det er dog ofte muligt at tilrettelægge egne undervisningsaktiviteter, formulere stillede problemformuleringer og at udarbejde egne vejledninger til opgaven. I dette arbejde er det centralt at sikre, at valg og materialer er kompatible med de overordnede rammer og mål (Skov, 2015). Den manglende interne sammenhæng kan ellers medføre, at underviserens pædagogiske praksis kommer i konflikt med censors forpligtelse til at bedømme efter studieordningens kriterier, hvilket kan påvirke eksamens validitet.

\section{Tip 2}

\section{Brug skrivning til at understøtte læreprocessen}

I undervisningens planlægning er det læringsfremmende at tilrettelægge aktiviteter, hvor de studerende kan skrive og får lejlighed til at forholde sig til det skrevne. Det giver både de studerende mulighed for at tilegne sig stoffet ved at arbejde aktivt med det og træner dem i at skrive.

Man kan fx tilrettelægge skriveøvelser, de studerende skal arbejde med i løbet af undervisningen, og disse kan gøres til genstand for feedbackprocesser eller selvevaluering (se tip 9). Det øger motivationen og læringsudbyttet, hvis studerende får mulighed for at anvende feedback fremadrettet, fx i forbindelse med omskrivning eller diskussion (Dysthe, 2011; Nicol \& Macfarlane-Dick).

Udover deciderede skriveøvelser er der mange andre måder, hvorpå underviseren kan integrere skrivning som læringsaktivitet i undervisningen (Bean, 2011). Ved introduktion af nyt stof og begreber i undervisningen kan man give de studerende 3-5 min. til at formulere deres forståelse ved $\mathrm{fx}$ at beskrive et konkret eksempel eller sætte det nye i relation til allerede kendt stof (Kristiansen, 2017). Det skrevne kan efterfølgende danne afsæt for diskussioner i mindre grupper eller i plenum. Man kan også arbejde med reflekterende skrivning, hvor studerende fx i slutningen af undervisningen nedskriver, hvad de vigtigste pointer var, eller hvad de fandt særligt svært, og derefter diskuterer deres svar med hinanden (Kristiansen, 2017). Endelig kan man også bede de studerende formulere sig på skrift som forberedelse, fx ved at besvare spørgsmål stillet af underviser eller formulere egne spørgsmål til en tekst og dele materialet på e-læringsplatformen inden undervisningen (Skov, 2015).

\section{Tip 3}

\section{Ekspliciter vurderingskriterier}

Studerende og undervisere deler ofte ikke forståelse af, hvad der "tæller" i en opgave, og studerende kan grundlæggende være i tvivl om, hvad formålet overhovedet er med deres opgave (Norton, 1990; Kristiansen, 2010; Hegelund \& Kock, 2003). Hvis de ikke forstår kravene til opgaven, så kan de ikke udvælge relevante skrivestrategier og opnår ikke det intenderede læringsudbytte.

Studieordningen indeholder en række kriterier, men man kan ikke forudsætte, at de studerende på egen hånd kan afkode disse (Skov, 2015). Det er derfor nødvendigt at bruge tid på 
at diskutere dem, give mulighed for spørgsmål og selv uddybe særligt vigtige pointer (Nicol \& Macfarlane-Dick, 2006). En del af de spørgsmål, der opstår i opgaveskrivningen fx i forhold til prioritering af stoffet, vil ideelt set kunne afklares ved at konsultere studieordningens beskrivelse af læringsmål. De studerende skal altså både lære at afkode en studieordningsbeskrivelse og bruge den aktivt undervejs i skriveprocessen.

De læringsmål, som er opstillet i studieordningen, vil sjældent kunne stå alene. For yderligere at eksplicitere og synliggøre kravene til opgaven, kan man udarbejde en rubric, dvs. et skema, der udfolder kriterier og giver mulighed for at vurdere, i hvilken grad de er opfyldt (Reddy \& Andrade, 2010). Udover at give en bedre forståelse af kravene til opgaven vil brugen af rubrics også kvalificere peer feedback (se tip 9). Man kan inddrage de studerende i arbejdet med at afkode og opstille kriterier, fx i forbindelse med en skriveøvelse.

Det hjælper også de studerende til at forstå kriterier, hvis de får udlevereret eksempler på konkrete, gode præstationer, som de kan bruge til at sammenligne deres eget og andres arbejde med (Orsmond et al., 2002).

\section{Tip 4}

\section{Synliggør argumentationens rolle}

For at kunne skrive gode opgaver er det en forudsætning at kunne argumentere på fagets præmisser og at kunne analysere og diskutere andres argumentation. Det er også en forudsætning at være bevidst om, at selvstændige opgaver er karakteriseret ved at være vidensproducerende og ikke blot vidensrefererende.

Som en metode til at give de studerende en forståelse for argumentationens rolle forslår Kock \& Hegelund (2003) at anvende Toulmins argumentmodel som en forståelsesramme for akademiske tekster som ét, overordnet argument. Toulmin anvender kategorierne påstand, belæg, hjemmel, gendrivelse, rygdækning og styrkemarkør til at synliggøre argumentationens enkelte delelementer og indbyrdes sammenhæng (Toulmin, 1958). Kategorierne er velegnede til at vise argumentstrukturer $\mathrm{i}$ akademiske tekster, herunder sammenhængen mellem data/materiale, teori, metode og metodediskussioner. Modellen kan både bruges som en analysemodel i forhold til andres tekster og som et arbejdsredskab i forbindelse med selvstændige opgaver.

I undervisningen kan man støtte de studerendes forståelse af argumentationens rolle ved fx at fremhæve udvalgte passager i forløbets tekster og sammen diskutere deres funktion i forhold til de overordnede pointer/fund. Man kan også analysere uddrag fra en opgave med henblik på at identificere og kategorisere de forskellige argumentelementer (Kock \& Hegelund, 2003).

\section{Tip 5}

\section{Diskuter forventningerne til selvstændighed i opgaven}

Selvstændighedsbegrebet kan forstås på mange forskellige måder (Jensen, 2018). Man kan derfor ikke forvente, at de studerende af sig selv kan afkode, hvad det indebærer at vise selvstændighed i det specifikke fag, eller at de har oplevet en progression i opgaveskrivningsarbejdet, der har rustet dem til at vise selvstændighed. Man kan heller ikke forvente, at de i udgangspunktet kan navigere mellem kravet til selvstændighed og kravet til at angive kilder. Det stigende fokus på plagiatkontrol kan i nogle sammenhænge føre til misforståelser og 
uheldige skrivestrategier, der direkte modvirker selvstændighed (Pittam, et al., 2009; Jensen et al., 2016). Så hvis der eksisterer en forventning om selvstændighed i opgaven (eksplicit eller implicit), er det nødvendigt at tale med de studerende om, hvordan de kan forstå kravet om selvstændighed inden for den specifikke faglighed, og hvordan de kan arbejde sig henimod at indfri dette krav på en konstruktiv måde. Hvad der i særlig grad fokuseres på er forskelligt på tværs af fag, men undervisere/vejledere vil ofte koble selvstændighed med fx emnevalg, problemformulering, teori- og metodevalg samt inddragelse af empiri og brug af kilder (Jensen, 2018; Rienecker et al., 2019).

\section{Tip 6}

\section{Diskuter krav til akademisk sprog}

Der hersker mange misforståelser om akademisk sprog. Det kan resultere i, at studerende skriver i et unødigt komplekst sprog, de ikke helt behersker, hvilket kan føre til næsten ulæselige opgaver. Andre fokuserer for ensidigt på finpudsningen af enkelte formuleringer og for lidt på fx at skabe sammenhængende argumentation. "Dårligt sprog" i opgaver kan også være et udtryk for en læreproces, et tegn på at studerende kæmper med at tilegne sig nye fagspecifikke skrivemåder og nyt stof. Udviklingen af skrivekompetencer er ikke en lineær proces, og det er normalt, at processen involverer regression (Gere, 2019; Kristensen, 2017).

Gennem diskussion af krav til akademisk sprog i undervisningen kan de studerende få lejlighed til at forholde sig til egne antagelser. Som et redskab til at diskutere emnet kan man inddrage Signe Skovs skema over kriterier for opgavesprog, der er inddelt i kategorierne videnskabeligt, klart og korrekt sprog (Skov, 2006; Skov, 2008). I diskussionen bør kriterierne kobles til faget gennem eksempler og gerne suppleres med fagspecifikke krav. Fremfor at have et rent anvisende sigte bør diskussionen inddrage baggrund og ræsonnementer for kriterierne og synliggøre koblinger til videnskabsteoretiske forståelser. Det kan åbne for et fælles refleksionsrum, der kan muliggøre en erkendelse af, at kravene ikke er statiske og entydige, men et resultat af kontinuerlige forhandlinger (Holm \& Clemensen, 2017). Denne bevidsthed kan hjælpe de studerende til selv at kunne analysere fremtidige kommunikationssituationer og træffe kvalificerede valg på egen hånd.

\section{Tip 7}

\section{Understøt problemformulerings- og litteratursøgningsprocessen}

Det er udfordrende for mange studerende at problemformulere og søge litteratur i forbindelse med skrivning af selvstændige opgaver. At give redskaber til at understøtte skriveprocessen (se tip 8) er en hjælp, men kan ikke stå alene.

Processen kan fx understøttes, ved at den studerende arbejder sig igennem en form for spørgeguide udarbejdet og evt. tilpasset til formålet. Booth et al. (2016) tilbyder en sådan spørgestruktur under overskrifterne From Topics to Questions og From Questions to a Problem (ibid. s. 33 ff.). Den interaktive problemformuleringsguide Scribo (Rienecker, 2014) opstiller også en række spørgsmål og kan derudover opsamle svarene og give adgang til eksempler på opgaver på tværs af fag. De tekster, de studerende producerer ved hjælp af sådanne spørgeguides, er velegnede til at danne udgangspunkt for peer-aktiviteter og underviservejledning. 
Begge de nævnte spørgeguides kobler problemformuleringsprocessen med litteratursøgning. At kunne formulere sit vidensbehov, orientere sig i og fremsøge kilder og kritisk evaluere disse er dybt forbundet med faglige læreprocesser og kan ikke forstås som en teknisk kompetence (Andreasen et al., 2008). De nævnte kompetencer er en forudsætning for at kunne situere en problemformulering fagligt i en selvstændig opgave. De studerende har derfor brug for at kunne udarbejde relevante søgestrategier samt at opnå en bevidsthed om, at arbejdet med at lave oversigter over søgeord og søgeskemaer kan være en frugtbar metode til at skærpe og afgrænse en problemformulering. Dermed bliver litteratursøgeprocessen $\mathrm{i}$ sig selv en vidensproducerende aktivitet (Bruce \& Hughes, 2010).

Man kan som underviser med fordel samarbejde med bibliotekernes informationsspecialister med kendskab til fagområdet, særligt hvis fokus er på at skrive selvstændige opgaver, hvor der er en forventning om, at den studerende selv finder og evaluerer kilder.

\section{Tip 8}

\section{Giv redskaber til at kvalificere skriveprocessen}

For at støtte de studerendes skriveproces kan man introducere opdelingen mellem tænkeskrivning og præsentationsskrivning (Dysthe et al., 2001). Tænkeskrivning (også kaldet processkrivning) dækker over tekst, der har til formål at frembringe/afprøve ideer og klargøre tanker, og som ikke vægter formelle krav. Præsentationsskrivning dækker over den færdige opgavetekst, der lever op til alle genrens krav. Tænkeskrivning er en metode til at arbejde sig hen mod færdig opgavetekst. Opdelingen kan hjælpe de studerende med at komme tidligere i gang med skrivearbejdet, at skrive bedre opgaver og kan afhjælpe udbredte problemer som fx udsættelse og perfektionisme (Dysthe et al., 2001, Elbow, 1973).

For både at understøtte de studerendes brug af tænkeskrivning og deres læring kan man inddrage aktiviteten i undervisningen. De studerende kan fx hurtigskrive (Elbow, 1973) i 5 min. om udvalgte faglige temaer eller spørgsmål og derefter få tid til selv at læse og revidere teksten. Øvelsen kan tjene som optakt til fx produktion af tekst til en wiki, skriveøvelser eller opgaveskrivning (Bean, 2011). Metoden kan understøttes gennem inddragelse af digitale redskaber (se fx nonstopskrivningsmodulet på Studypedia.au.dk; Jensen og Koefoed, 2003).

Akademisk skrivning indebærer at arbejde med revision af tekster. Revision kan kvalificeres ved at de studerende forholder sig til teksten på et globalt niveau før et lokalt niveau (Dysthe et al. 2001). Dyste et. al (2001) forslår, at man i prioriteret rækkefølge fokuserer på følgende fem niveauer: skrivesituation (formål, modtager); indhold og struktur; sætninger; ordvalg og retskrivning og endelig tegnsætning og formalia. Alle niveauer er vigtige, men modellen kan orientere studerende mod at forholde sig til tekstens overordnede formål, argumentation og struktur, før de sætter fokus på specifikke formuleringer og tegnsætning. Det giver fx ikke meget mening at arbejde længe på at finpudse sætninger, der så viser sig indholdsmæssigt ikke at have en plads i den overordnede argumentation. Princippet kan også med fordel anvendes i forbindelse med feedback.

Skriveprocesser er ofte usynlige i undervisningen. Det kan derfor være lærerigt at diskutere, på hvilke betingelser faglige tekster er blevet til, fx hvordan de ofte gennemgår gentagne omskrivninger på baggrund af peer reviews. Dette vil være med til at synliggøre, at revision og omskrivning af tekst er en naturlig del af skrivearbejdet. Underviseren kan også vælge at inddrage eksempler på egne tekster på forskellige stadier for at give indblik i, hvordan en faglig tekst kan udvikle sig. 


\section{Tip 9}

\section{Integrer struktureret peer feedback og selvevaluering}

Feedbackforskningen viser, at peer feedback på skriftlige produkter kan være en effektiv metode til at lære. Når de studerende skal forberede og give kriteriebaseret feedback, arbejder de aktivt med at forstå og tilegne sig kriterier for faglige tekster. Denne træning overfører de efterfølgende i arbejdet med deres egne opgaver (Nicol, Thomson \& Breslin, 2014; Gibbs, 1999). Dermed indeholder peer feedback et stort læringspotentiale, der ikke nødvendigvis forløses ved underviserfeedback, der gives i forbindelse med en karakter (Butler, 1987). Peer feedback anvendes som formativ feedback, så de studerende får mulighed for at anvende den feedback, de modtager, fremadrettet (Nicol \& Macfarlane-Dick, 2006; Sadler, 1989). Man kan fx introducere skriveøvelser, hvor studerende efter peer feedback får mulighed for at arbejde videre med teksten, inden evt. aflevering til underviser.

For at peer feedback får den ønskede effekt, er det vigtigt, at studerende forstår rationalet bag metoden og får retningslinjer til at arbejde med den i praksis. Det vil fx være nødvendigt at skabe en fælles forståelse af, at arbejdet med at give andre feedback udgør et vigtigt træningsrum for opbygning af egne skrivekompetencer. Det er også nødvendigt med fælles retningslinjer for, hvordan man giver og modtager feedback, for at kvalificere processen og for at undgå, at negative sociale dynamikker opstår (Dysthe, Hertzberg \& Hoel, 2001; Hvass \& Heger, 2018). Der findes både digitale og analoge redskaber, der kan strukturere og understøtte peer feedback i undervisningen (Peergrade, se fx Bertel \& Bentzen, 2018; Tekstfeedbackspillet, se fx Jensen, Jensen \& Jørgensen, 2013).

Peer feedback sigter mod at sætte den studerendes egne handlinger i undervisningen $\mathrm{i}$ fokus og give dem mulighed for at oparbejde en evne til selv at foretage valg og vurderinger, baseret på ekspliciterede kriterier i deres skriftlige arbejde. En anden metode til at opnå denne evne er selvevaluering, hvor de studerende får mulighed for løbende at vurdere egne præstationer og øve sig i at regulere deres egen læring på en struktureret måde (Nicol \& Macfarlane-Dick, 2006). Man kan fx bede studerende om selv at identificere styrker og svagheder ved deres tekst i forhold til ekspliciterede kriterier og aflevere refleksionerne på skrift inden evt. underviserfeedback.

\section{Konklusion}

Det er især undervisere på forløb med skriftlige eksamensformer, som har et ansvar for at understøtte de studerende i at oparbejde de nødvendige faglige skrivekompetencer, men i alle sammenhænge kan skrivning integreret i den specifikke fagdisciplin anvendes som en effektiv metode til at lære.

Da den faglige disciplins egenart spiller en så afgørende rolle, kan man ikke give en entydig opskrift på, hvordan man bedst arbejder med akademisk skrivning - det afhænger af fagets genstandsområde, tænkemåder og vidensforståelser. Men de ni tips præsenteret i denne artikel tilbyder undervisere på tværs af fag et fleksibelt udgangspunkt til at tilrettelægge deres undervisning, så den kan understøtte opbygningen af akademiske skrivekompetencer og læring. 


\section{Referencer}

Andreasen, L. B., Jørgensen, L., \& Nielsen, J. L. (2008). Udvikling af informationskompetence i problemorienterede læreprocesser. Antologier, 75-90.

Bean, J. C. (2011). Engaging Ideas: The Professor's Guide to Integrating Writing, Critical Thinking, and Active Learning in the Classroom. John Wiley \& Sons.

Bertel, T. F., \& Bentzen, T. Ø. (2018). Formativ evaluering med IT-systemet Peergrade. Tidsskriftet Loering og Medier (LOM), 10 (18).

Biggs, J.B. \& Tang, C. (2007). Teaching for Quality Learning at University (3rd ed.). Buckingham: SRHE and Open University Press.

Blåsjö, M. (2004). Studenters skrivande i två kunskapsbyggande miljöer. Acta Universitatis Stockholmiensis. Stockholm Studies in Scandinavian Philology. New Series. 37. Almqvist \& Wiksell International.

Booth, C, G. G. Colomb, J.M. Williams, J. Bizup \& W. T. Fitzgerald (2016) The Craft of Research, The University of Chicago Press

Bruce, C., \& Hughes, H. (2010). Informed learning: a pedagogical construct attending simultaneously to information use and learning. Library \& Information Science Research, 32(4), A2-A8.

Butler, R. (1987) Task-Involving and Ego-Involving Properties of Evaluation: Effects of Different Feedback Conditions on Motivational Perceptions, Interest and Performance, Journal of Educational Psychology, 78(4), 210-216.

Carter, M., Ferzli, M., \& Wiebe, E. N. (2007). Writing to Learn by Learning to Write in the Disciplines. Journal of Business and Technical Communication, 21(3), 278-302.

Dysthe, O., Hertzberg, F., \& Hoel, T. L. (2001). Skrive for at loere. Århus: Forlaget Klim.

Dysthe, O., \& Engelsen, K. S. (Eds.). (2003). Mapper som pedagogisk redskap: Perspektiver og erfaringer. Abstrakt.

Dysthe, O. (2011). 'What is the Purpose of Feedback when Revision is not Expected?' A Case Study of Feedback Quality and Study Design in a First Year Master's Programme. Journal of Academic Writing, 1(1), 135-142.

Elbow, P. (1998). Writing Without Teachers. Oxford University Press, USA.

Gibbs, G. (1999) Using assessment strategically to change the way students learn, in: S. Brown \& A. Glasner (Eds) Assessment Matters in Higher Education: Choosing and Using Diverse Approaches (Buckingham, SRHE/Open University Press).

Hagström, E. 2005. Meningar om uppsatsskrivande i högskolan. Ph.d.-afhandling. Örebro University, Department of Education.

Hegelund, S., \& Kock, C. (2003). A Good Paper Makes a Case: Teaching Academic Writing the Macro Toulmin Way. In Teaching Academic Writing in European Higher Education (pp. 75-85). Springer, Dordrecht.

Hvass, H., \& Heger, S. 2018 Brugbar peer feedback: Instruktion og træning, før de studerende 
selv skal give og modtage. Dansk Universitetspaedagogisk Tidsskrift, 13(25), 59-70.

Holm, L., \& Clemensen, N. (2017). At lære sig" de kloge damers" sprog: Studerendes perspektiver på akademisk skrivning. Dansk Universitetspaedagogisk Tidsskrift, 12(23), 37-51.

Ivanič, R. (1998). Writing and Identity. John Benjamins Publishing Company.

Jensen. T.W. (2018). Det danske universitetsspeciale - topografi, tekster og tendenser. Aarhus Universitetsforlag.

Jensen, T. W. \& Hansen, L. K. (2003). Next Stop in the Study Metro: Supporting Learning of Freewriting by Providing Interactive Feedback. In World Conference on Educational Multimedia, Hypermedia and Telecommunications (Vol. 2003, No. 1, pp. 1291-1296).

Jensen, T. W., Jensen, G. S., \& Jørgensen, A. H. (2013). Tekstfeedbackspillet: en metode til at strukturere peer feedbackprocessen. I R. Troelsen, \& L. Rienecker (red.), 17 ting, du kan gøre ved din undervisning, DUNK12 Konferencepublikation. (s. 61-66), Dansk Universitetspædagogisk Netværk (DUN).

Jensen, T. W., Bay, G., \& Andersen, P. (2017). Udvikling af studerendes akademiske skrivekompetence - en model for en indsats på fakultetsniveau. Dansk Universitetspaedagogisk Tidsskrift, 12(22).

Kristiansen, B. (2017). Om at skrive på universitetet. Syddansk Universitetsforlag.

Kristiansen, B. (2010). Tekstproduktion og vidensproduktion. Dansk Universitetspaedagogisk Tidsskrift, 5(9), 50-54.

Lea, M. R. \& B. V. Street. 1998. "Student Writing in Higher Education: An Academic Literacies Approach." Studies in Higher Education 23.2.

Nicol, D. J., \& Macfarlane-Dick, D. (2006). Formative Assessment and Self-Regulated Learning: A Model and Seven Principles of Good Feedback Practice. Studies in Higher Education, $31(2), 199-218$.

Nicol, D., Thomson, A., \& Breslin, C. (2014). Rethinking Feedback Practices in Higher Education: A Peer Review Perspective. Assessment \& Evaluation in Higher Education, 39(1), 102-122.

Norton, L. S. (1990). Essay-Writing: What Really Counts?. Higher Education, 20(4), 411-442.

Olsen P.B. \& K. Pedersen. (2018). Problemorienteret projektarbejde. Samfundslitteratur

Orsmond, P., Merry, S., \& Reiling, K. (2002). The Use of Exemplars and Formative Feedback when Using Student Derived Marking Criteria in Peer and Self-Assessment. Assessment \& Evaluation in Higher Education, 27(4), 309-323.

Pittam, G., Elander, J., Lusher, J., Fox, P., \& Payne, N. (2009). Student beliefs and attitudes about authorial identity in academic writing. Studies in Higher Education, 34(2), 153170.

Reddy, Y. M., \& Andrade, H. (2010). A review of rubric use in higher education. Assessment \& Evaluation in Higher Education, 35(4), 435-448.

Rienecker, L. (2014). Scribo. Samfundslitteratur 
Rienecker, L. \& P.S. Jørgensen. (2017). Den gode opgave - håndbog i opgaveskrivning på videregående uddannelser. Samfundslitteratur.

Rienecker, L., G. Wichmann-Hansen \& P.S. Jørgensen (2019). God vejledning - af specialer, bacheloropgaver og projekter. Samfundslitteratur.

Sadler, D. R. (1989). Formative assessment and the design of instructional systems. Instructional Science, 18(2), 119-144.

Skov, S. (2015). Loeringsorienterende kursusdesign. Samfundslitteratur.

Skov, S. (2006). Hvordan bedømmer man det sproglige i universitetsopgaver? Dansk Universitetspoedagogisk Tidsskrift, 1(1), 18-25.

Skov, S. (2008.) Bundne opgaver - hjemmeopgaver og eksamensopgaver på videregående uddannelser. Samfundslitteratur.

Toulmin, S. E. (2003). The Uses of Argument. Cambridge University Press.

Wingate, U. 2006. "Doing away with 'study skills'." Teaching in Higher Education. 11.4:457469.97 